\title{
THE GLOBAL POLITICAL IMPACT OF THE CORONA-VIRUS PANDEMIC
}

\author{
Mihaela HUŞANU ${ }^{14}$
}

\begin{abstract}
The Coronavirus pandemic has put profound pressure on the democratic electoral system around the world. Many national and regional elections, as well as referendums were postponed, while others took place in a form adapted to the acute health crisis. The pandemic affected not only the actual conduct of election campaigns, which, due to health restrictions, used the online environment extensively, but also national public agendas. Issues such as public health, social and economic inequality, violations of individual rights and freedoms, as a result of measures to prevent the risk of infection with the SARS-CoV-2 virus, have come to the fore. The crisis has generated unpredictable and potentially disastrous results, from the collapse of mainstream (traditional) parties to the emergence of new leaders and new political parties, some with strong extremist orientations. How has the Coronavirus pandemic changed the perception of the electorate and how has this perception influenced voting in times of crisis?
\end{abstract}

Keywords: pandemic; Coronavirus; crisis; democracy; elections; impact

Ignited at the end of 2019 and declared a pandemic by the World Health Organization (WHO) in March 2020, COVID-19 has brought to the fore a number of broad challenges for democracy and human rights.

More than a threat to public health, in the absence of conclusive information on the contagiousness and predictability of the evolution of the infection with the new type of SARS virus, the pandemic has forced governments and state authorities around the world to take emergency measures in order to combat the health crisis consequences triggered by Coronavirus. These urgent measures were based on the restriction or limitation of rights and freedoms guaranteed by law (eg. internal and external movement, freedom of assembly and association, freedom of the press and of the justice), which often have been disproportionate compared to the gravity of the danger and have generated discriminatory effects, with a significant impact on democracy and freedom. Poor communication, lack of transparency in decisions and lack of arguments for the restrictive provisions adopted are common to both repressive regimes and open, democratic societies that have responded to the pandemic in ways which serve political interests rather than public health and individual freedoms.

\footnotetext{
${ }^{14}$ Ms. Mihaela Hușanu is media and communication strategist, with more than a decade of experience in the communication and public relations field. Ms. Huşanu is image counselor, political consultant and spokesperson within regional governmental institutions in Romania.
} 
Pressures on basic rights and freedoms have been felt more sharply in states where the Coronavirus crisis has overlapped the election cycles. If, in some countries, the postponement of elections was imposed as a last resort, being supported by law and with a broad consensus between political forces and independent experts, in most states elections took place on time or national, regional elections and referendums have been rescheduled.

The transformations that have affected the democratic electoral systems concern not only the procedures of properly organizing the elections, from the way of conducting the electoral campaign to the way of exercising the right to vote, by each voter, but especially the national and international public agendas, with some nationalist, ultra-radical themes being overexposed and with the major, lasting affectation of the public perception.

This paper aims to examine how pandemic democracy influenced voting in times of crisis, given that many of the election results that took place in the new health context were unpredictable and with a potentially disastrous impact on values, democratic norms and principles.

For better understanding the effects of the pandemic on a democratic system, we deepened the analysis in a case study regarding the parliamentary elections that took place in Romania in December 2020, elections that conducted to the collapse of mainstream (traditional) parties and the emergence of new leaders and new political formations, some of them with strong extremist orientations.

\section{PANDEMIC DEMOCRACY AND VOTING UNDER CRISIS}

Democratic elections are an expression of sovereignty, and their fairness is a necessary condition for democratic governance, according to the international organization National Democratic Institute (NDI).

The Coronavirus pandemic has called into question the ability of many countries to guarantee fair and transparent elections, as a result of the total or partial disruption, to the impact of COVID-19, of that legal and administrative framework that ensures a responsible, genuine, free and equal electoral process.

In fact, COVID-19 has brought with it not only a health and economic crisis, which many states have tried to deal with by declaring a state of emergency and taking measures to prevent the spread of the virus, but also a crisis of democracy and good governance ${ }^{15}$, during which human rights have been undermined and freedoms eroded.

The crisis has revealed specific shortcomings in the performance of states, which were felt more strongly in the case of weak states, but also affected strong states. Functional gaps (the capacity of the authorities to provide security to all citizens, legitimate political institutions, efficient economic management and

\footnotetext{
${ }^{15}$ Dobrescu, P., Crisis after crisis. A world without compass and without hegemon, Litera Publishing House, Kronika Collection, Bucharest, 2016.
} 
basic social welfare) have been exacerbated and eroded the ability of states to govern themselves from an economically point of view (in the event of total quarantine or partial closure of different sectors of economic activity) and to provide essential services to the population (medical services, for example, after hospitals have been closed and transformed into support units for the treatment of COVID-19 patients).

In addition to the specific problems it has raised, the Coronavirus crisis has shaken governments around the world by inducing a derailment from the natural order, replacing the naturalness of governments with uncertainty, confusion and lack of control. All this can very quickly lead to the installation of a climate of insecurity, which tends to be correlated with voids of political and economic power ${ }^{16}$. During crises, including those triggered by epidemics, the problem of the weak state concerns a matter of capacity (resilience), rather than one of will. There is, therefore, a risk that the authorities will waste their energy and resources in a diffuse form, in a non-uniform and unfocused effort on eliminating the triggers of the crisis (for example, on the laborious purchase of protective equipment, instead of prompt initiation of procedures for mass testing).

Knowing that a crisis represents "the convergence of events whose combination produces a new set of circumstances" ${ }^{17}$, and that control over events and their effects decreases in such circumstances ${ }^{18}$, it is interesting to analyse how uncertainties related to the assessment of the situation and the alternatives at hand have been exploited, in the context in which urgency has often made information inadequate.

Opportunistic authoritarian governments have used COVID-19 as a means of preserving and expanding their executive power, to the detriment of the formal rule of law, legislative oversight and human rights. Thus, were adopted laws which increased the power of institutions with a decision-making role in the state and with powers to impose restrictive provisions, to the detriment of other institutions, the official purpose of the state being to limit the spread of the virus. On the other hand, the health crisis has been a pretext for some authorities to further restrict democratic approaches and to silence critical voices in their societies. Those in power have often been accused by the opposition and other critics of trying to shape the election calendar to their advantage, either by lifting restrictions too early to allow the resumption of the electoral process (for example, as in Serbia - the first European country to held parliamentary elections after the crisis) or the unnecessary prolongation of transitional situations (such as in Bolivia, which has an interim president). In fact, several countries have been

\footnotetext{
${ }^{16}$ Stewart, P, Weak states and global threats: fact or fiction? "The Washington Quarterly", no. 29: 2, 2006, pp. 27-45.

${ }_{17}$ Wiener, A.J., Kahn, On Escalation, New York, Praeger, apud. Lagadec, P, Prevention of Crisis Chaos Strategies for Combating, Controlling and Limiting Damage, London: McGraw - Hill Book Company, 2003, pg. 43.

${ }^{18}$ Ibidem.
} 
caught in the Coronavirus crisis in a state of transition, with governments or interim presidents (e.g. Bolivia, Sri Lanka and Northern Macedonia), while in other states, such as Mali and Guinea, where elections have already been delayed long before the pandemic itself, making postponement even more problematic from a constitutional perspective.

Abuse of authority prevailed in countries where governments have decided to unequivocally cancel elections and without considering possible measures to mitigate the electoral risks of the pandemic, including postponing election dates and remote voting (by mail or electronically).

In other countries, the elections that were originally scheduled for 2020 have been postponed, supposing to take place either when the epidemiological situation was to improve and the number of cases of SARS-CoV-2 infection was to decrease, or in 2021.

Ideally, the postponement of elections should involve a responsible decision that takes into account both the democratic imperative, enshrined in international law and national constitutions, on the holding of regular elections, and the public health imperative, where meetings are severely restricted and physical contact is minimized.

From 21 February 2020 to 9 May 2021, at least 78 countries and territories around the world have decided to postpone national and regional elections because of COVID-19. Of these, at least 41 countries and territories have decided to postpone national elections and referendums, according to a report by the International Institute for Democracy and Electoral Assistance (IDEA). There are 26 states in Europe (including France, Great Britain, Spain, Sweden, Romania), 3 states in the Middle East (Iran, Syria and Oman), 14 states in Africa (including Libya, Tunisia, Botswana, South Africa), 18 countries in the Americas (including Canada, Colombia, Mexico, Argentina), 17 countries in the Asia-Pacific region (e.g. India, Pakistan, New Zealand, Papua New Guinea) - according to the tables in the Appendix.

On the other hand, at least 118 countries and territories have decided to hold national or regional elections, despite concerns about COVID-19, of which 97 have held national elections or referendums. At least 53 countries and territories held elections that were initially postponed due to the Coronavirus crisis, of which 28 held national elections or referendums. There are 35 European states (e.g. Germany, Poland, Lithuania), 4 from the Middle East (Jordan), 26 African states (Nigeria, Egypt, Kenya, Ghana, Algeria), 25 American states (USA, Peru, Venezuela), 28 states from the Asia-Pacific area (Myanmar, Mongolia, Kazakhstan).

Decisions to postpone national elections also had a significant impact on local and regional elections. For example, the Russian government postponed the vote on the Constitutional Referendum on April 22, 2020, as well as all elections originally scheduled from April 5 to June 23, 2020, with approximately 94 local 
and regional electoral processes being suspended. The referendum later took place on July 1, 2020.

\subsection{How pandemic elections were held}

The rights of citizens to vote and to be elected in democratic elections are internationally recognized as human rights and are enshrined in national constitutions.

Moreover, there are numerous international and regional instruments stipulating that elections must take place regularly, by universal, equal and secret ballot. These instruments include the Universal Declaration of Human Rights Article 21 (3), International Covenant on Civil and Political Rights (ICCPR) Article 25, Protocol no. 1 to the European Convention on Human Rights (ECHR) on the right to free choice - Article 3, Document of the Copenhagen Meeting (1990) of the Conference on the Human Dimension and the Conference on Security and Cooperation in Europe (CSCE, now OSCE), American Convention on Human Rights - Article 23 (1.b), African Charter on Democracy, Elections and Governance - Article 3 and Declaration on Human Rights of the Association of Southeast Asian Nations (ASEAN).

However, international law does not exclude the possibility of restricting certain human rights, including political rights, in the event of an emergency. According to ICCPR, some basic rights cannot be derogated, do not allow any limitation, such as the right to life, release from torture, cruel, inhuman or degrading treatment or punishment, freedom from slavery or involuntary servitude, etc. Political rights, on the other hand, including the right to vote, may be restricted in emergency situations, including on public health grounds, but these restrictions must comply with the standards of legality, necessity, proportionality and temporality. Moreover, according to the Syracuse principles adopted by the UN Commission on Human Rights, it is the obligation of a state that imposes restrictions to demonstrate that these limitations do not affect the functioning of the democratic system.

Ensuring and respecting fundamental rights must be a priority when holding elections during the pandemic, as set out in the Venice Commission's report on "Respect for democracy, human rights and the rule of law during emergencies". Postponement of elections, notes the Venice Commission, involves political risks, and the loss of democratic control over representatives or governments, for a period of time, is a more problematic situation in countries already facing democratic slippage.

Undoubtedly, the Coronavirus crisis has brought to the forefront of international public debate an ethical conflict between the right to life, health and safety, which have been jeopardized by COVID-19, and the right to vote. To ensure that all these fundamental rights are properly respected, governments have been put in a position to find a stable balance between protecting the lives, health 
and safety of the population and holding democratic elections that do not involve risks to participants. "There is a fine line between protecting our democracies and protecting public health. Both national and EU institutions must ensure that all Member States comply with the law and that our democracies will emerge stronger and not weaker after the end of the Covid-19 pandemic", a report by the European Union on Civil Liberties said in a statement and Greenpeace Europe ${ }^{19}$.

In order to protect public health and, at the same time, the integrity of the electoral process, the general recommendations issued by the WHO aimed in particular at coordinating the planning and implementation by the authorities involved in organizing elections of all necessary measures for the conduct of electoral processes during public health crisis.

Given the different intensity, at international level, of the COVID-19 pandemic, the authorities had total autonomy to decide on the organization and conduct of elections, different countries standing out through the way they created and applied the legal provisions related to the pandemic context. Mainly, strict rules have been imposed for the prophylaxis, protection and prevention of the spread of the virus in polling stations: wearing masks and gloves, maintaining adequate physical distance, measuring body temperature, disinfecting hands and surfaces in polling stations, in booths vote, and other election materials (stamps). As for the voters infected with Coronavirus, they had the opportunity to express their political choice in the polling stations, only equipped with a protective mask, either during or after the closure of the official program, ensuring separate access corridors.

Specific measures were also needed for vulnerable groups (the elderly or people with certain health conditions or hospitalized people etc.), who were provided with adequate voting options, according to the electoral regulations. To reduce the risk of infection, people in these groups were encouraged to express themselves through alternative voting methods, even if the general population voted in person. For example, in South Korea, provisions have been extended for home voting for hospitalized persons, which have ensured the protection of vulnerable citizens. As a result, polling stations were relocated to the area close to communities and care units for the elderly. Alternatively, there were polling stations only for vulnerable groups.

With regard to the production and distribution of ballot papers, ballot boxes, seals and other supplies required during the electoral process, they were sometimes severely affected by the measures imposed to limit the spread of the virus. There were delays in their production and delivery, and all previous appointments were adjusted to the new conditions (for example, in the USA).

\footnotetext{
${ }^{19}$ Drăghici, M., Pandemic has eroded democracy and the rule of law in many EU countries, including Romania, March 2021, available at: https://www.mediafax.ro/social/organizatie-pandemia-a-erodat-democratia-si-statul-dedrept-in-multe-tari-ue-inclusiv-in-romania-19950571, accessed on 17.05.2021.
} 
Among those who held elections in times of crisis, South Korea stood out as a model for high-level organization of a successful electoral process (with the possibility of early voting), while protecting the health of its people. South Korea was, in fact, the first country to hold national elections amid the global outbreak of COVID-19 in April 2020. Voters were not only interested in the election, despite the risk of infection, but proved to be the most numerous in the last 28 years. South Korea has not reported any new cases of COVID-19 directly related to the April 15 elections, despite the fact that they took place at an early stage of the pandemic. Other countries, such as Burundi, have set a negative standard, completely ignoring health risks and endangering both the population and politicians. The election campaign in Burundi was unrestricted: numerous teams toured the country, political parties hosted events and rallies with thousands of supporters. Candidates did not wear masks and water and disinfectants were missing. All this, while neighbour countries such as Rwanda and the Democratic Republic of Congo considered full quarantine, due to the increased number of cases of infection.

In order to limit the effects of the spread of the virus that took the world by surprise, the governments of the states where the polls took place used the online environment during the elections organization, according to the WHO. Thus, measures were introduced such as online or e-mail registration of voters, virtual training of qualified staff in polling stations, online submission of ballots and online complaints about the electoral process, electronic resolution of electoral disputes. All this has left the traditional version of the polls, the offline one, somewhere in the past.

From this perspective, one can admit that, in addition to the negative effects of the crisis (millions of deaths, the collapse of health systems and the bankruptcy of many of the world's economies), COVID-19 has made a decisive contribution to speeding up the reform of electoral systems. Increasing the access to voting for vulnerable voters, through the wider use of the digital environment and new technologies, in addition to early voting by mail, is, however, only one side of the coin. The correctness, safety and integrity of the vote are the reverse. This is because remote voting, by e-mail or the Internet, involves not only technical risks, but also major risks of fraud, either from the authorities, or from hackers, or from hostile foreign factors that could have an interest in hijacking election results in certain states.

No less important is the fact that the Cyber Infrastructure Security Agency within the US Department of Homeland Security has repeatedly warned with the risks of e-mail voting, which entails significant security breaches in terms of both vote integrity and the confidentiality of voter data, as well as the secrecy of the ballot paper and the capacity of the voting system. Recent election history shows that electronic voting systems are more susceptible to fraud (for example, Russia's hacking campaign during the US election). The pandemic does not provide the 
right context for online voting, as this type of voting requires a gradual, multiround vote to improve system reliability and gain voter confidence, as evidenced by the experience of Estonia - the only country with large online voting.

We already see that the reform of electoral systems entails a significant dose of distrust on the part of voters, given that governments cannot guarantee the fairness and transparency of elections, nor the secrecy of the vote, as evidenced, for example, by controversies in several countries, around voting by mail. In the US elections (2020), significant losses of votes were revealed in the postal system, and many votes were no longer counted, due to the lack of ballot markings or failure of the voters' identification. In these circumstances, it is important the call made by the Carnegie Foundation, which pointed out that not only early voting and postal voting should be extended in the future, but new investments in voters' education are needed for the democratic electoral system to work.

The key word of a crisis is inevitability, and the inventory of potential events that could exacerbate these crises is very important in what constitutes an emergency management or what Bernard Dagenais calls "stake management", because any crisis contains both the seeds of success, as well as the roots of failure" $" 20$.

\subsection{Elections campaigns during pandemic}

Probably one of the biggest challenges in conducting elections was, in the midst of the outbreaks of Coronavirus in 2020, the organization of election campaigns. These traditionally involve large gatherings of people and direct physical contact. The relocation of election campaigns to the digital space, following the WHO recommendations to limit the spread of the COVID-19 epidemic, turned out as a real paradigm shift: social contact, once vital in democratic elections, during which elections are won through dialogue and debate, has now been mediated mainly by new technologies.

Given that the meetings with supporters did not took place or were limited to a small number of participants, while maintaining their physical distance, the candidates and campaign teams had to rethink the communication bridges with potential voters. In addition to traditional media (TV, radio, print media, electronic media), social networks (Facebook, Twitter, Instagram, YouTube, WhatsApp) have become platforms for launching election messages, thus being the main digital interface between electoral competitors and the electorate.

The United States, known for the extensive vibrant campaigns for both Congress and presidential elections, is an eloquent example of a pandemic democratic compromise, with the mix of traditional and online campaigns imposed by COVID-19 restrictions being relevant for the adaptation of democracy to an emergency situation. Joe Biden, the Democratic candidate in the presidential election, very well speculated on the need to strengthen his presence in the press,

\footnotetext{
${ }^{20}$ Larkin, J, Regester, M., Crisis and Risk Management, Bucharest: Comunicare.ro Publishing House, 2003 , p. 61.
} 
so he decided to use his own television studio, set up in his home. Large-scale election rallies provide the best place in the news bulletins, and Republican President Donald Trump understood this when he held his first big rally in Tulsa, Oklahoma, in a closed arena, despite serious risks to participants' health. Two weeks after the rally, Tulsa saw a significant increase in Coronavirus cases, but all participants in the event have already signed waivers in case of illness.

Donald Trump's rally was not the only negative exception, fierce electoral competition leading to large-scale events in other countries than the United States. In Malawi, for example, both presidential candidates met with voters at major election rallies, fully contributing to the rise in infections. The country has been in a political crisis since the Supreme Court annulled the May 2019 presidential election due to widespread irregularities. The election of June 23, 2020 brought a clear victory to the opposition candidate.

The limitation of face-to-face election campaigns has accentuated the already existing asymmetries between candidates in terms of access to the media. In this sector, the electoral games between the power and the opposition were to the advantage of the power, which had already taken over the media space through the themes of pandemic measures, new public policies and recurring messages, which appealed to everyone's responsibility. In Serbia, where large parts of the media landscape are controlled by the ruling party, incumbent President Aleksandar Vučić has taken advantage of his access to the media to promote himself through his achievements in the fight against Coronavirus and to criticize the opposition. The strategy was a winning one, with Vučić's party winning the first general election in Europe since the beginning of the pandemic. In the United States, too, President Trump has maximized the effect of daily reporting on Coronavirus, successfully replacing election rallies with laudatory statements about his policies and criticism of his competitors.

Moving election campaigns to the online environment also meant taking an enormous risk, difficult to anticipate and counteract, regarding the distribution of election messages. It is a well-known fact that the ferocity of "negative" social media users, who do not know ethical principles and who intentionally use the virtual space for their interests, reaches its peak during political campaigns. The most common attack techniques of these "negative" users are astroturfing and trolling ${ }^{21}$. Astroturfing is a very common behaviour in political communication and refers to the posting of false positive messages by partisan or paid users, being nothing more and nothing less than an artificial form of propaganda in support of a public, political or institutional agenda, in order to create the impression of a "rooted movement". Trolling refers to the posting of comments on personal sites (blogs and social networking accounts), the aim being to generate conflict and a negative climate towards the owner. During the Coronavirus crisis, electoral

\footnotetext{
${ }^{21}$ Cismaru, D.M., Ciochina, R.S., Public relations in the online environment, Bucharest: comunicare.ro Publishing House, 2019, p. 135.
} 
contestants took full advantage of the fact that, in the reality of social distancing, many activities moved to the online space, turning the electronic environment into an arena for electoral slogans and fake-news.

\subsection{Public agenda during pandemics}

Simultaneously with the messages distributed by traditional media, social networks have taken over and multiplied the themes imposed on the international public agenda by the COVID-19 pandemic, respectively health, economic and social issues, to the detriment of other topics of interest for preserving or revitalizing democracy in some states.

First, the decision to have referendums in times of crisis and moreover the election calendar have been the subject of hot disputes between governments and opposition parties in many countries. For democracy, the Coronavirus crisis was rather a "double-edged sword", as characterized in a report by the Belgian Egmont Institute for International Relations. On the one hand, this sword could be used as a powerful tool to postpone the elections, by a government regime that wanted to extend its mandate, or as an ally in the fight against political opponents, the harsh restrictions imposed limiting their ability to organize public gatherings and other campaign events. No less true is that some governments wanted to optimize their electoral capital, relying on extensive press campaigns highlighting the success of pandemic measures, before the socio-economic effects of the crisis became fully evident.

Secondly, the opposition parties speculated as much as possible any democratic slippage, starting with the legal measures that violated a number of fundamental individual rights and freedoms. Freedom of internal and external movement was restricted, for public health reason, with the introduction of full quarantine or at certain time intervals. Freedom of assembly and association was restricted by imposing regulations on the occupation of a certain space by a certain number of persons. Freedom of expression and freedom of the press have been suppressed under the pretext of combating misinformation, the activity of civil society organizations being also limited by measures against Coronavirus. Freedom of justice was also affected because the activity of the courts was significantly reduced during the state of emergency, with state-level non-uniform practices on the types of cases that were at trial during the pandemic.

We can admit that the COVID-19 pandemic has exacerbated trends towards democratic failure and authoritarian consolidation, if we only consider the fact that authoritarian regimes have taken advantage of the restrictions imposed to silence dissidents and stop protests. An example of this is Algeria, where weekly anti-government demonstrations have been cancelled for the first time in more than a year, to reduce the spread of Coronavirus. On the other hand, slow democratic progress could be undermined by the COVID-19 crisis, as in the case of Chile, where the Coronavirus postponed the Constitutional Referendum for the 
adoption of the first democratic constitution in recent times. Amid the economic crisis, doubts have arisen in Chile about the feasibility of constitutional reform.

Social issues also appeared in the public spotlight after the Coronavirus pandemic fundamentally changed the world's economic landmarks. Thus, the strongly nationalist discourses returned in force, being accentuated by topics such as resilience, solidarity, cohesion, equity, the fight against poverty, the fight against social inequalities, the need to leave no one behind. Electoral contestants came to the polls either with programs aimed at turning the crisis into an opportunity for a solid and sustainable socio-economic reconstruction, or with nationalist and ultra-nationalist platforms, which claimed the right of the state to pursue exclusively its own interests, post-pandemic.

There have also been voices arguing that ethical issues related to the allocation of resources and the degree of risk to which some citizens are subjected during a pandemic impose the need to apply strict rules, which can sometimes be perceived as unfair. Other opinions (Moldovan, 2020) strongly argued that, for the successful management of this crisis, public policies must be anchored in rigorous scientific studies, in the principles of ethics and the rule of law ${ }^{22}$.

In Romania, the topic of pandemic politicization was not a new one, the existence of this trend being noticed in more consolidated democracies and public spaces, where the subject was included in a larger one, regarding the geopolitization of the health crisis. Beyond being "the first pandemic of globalization, the first pandemic of the digital age, hyperconnection and information hyperinflation", it was also "the first politicized pandemic right in the middle of liberal democracies and the first geopolitical pandemic"23.

The recurrence on the public agenda of issues such as the lack of capacity of the state to respond promptly and effectively to crisis situations (incidents in the overburdened medical system) has led to the loss of citizens' trust in public authorities and institutions, impossible to handle. Continuously maintained, the fear and insecurity of the people sought and found refuge in anti-system electoral rhetoric and in a true conspiracy rhetoric. In fact, the way in which these conspiracy theories emerged "suggests at least two themes for reflection: one concerns the instability of state-building, and the other concerns the susceptibility of a significant portion of the general public to these theories, despite their subterfuge" 24 .

The authorities' approaches to manage the health crisis were either reactive (weak states) or proactive and interactive (strong states). However, there were some general strategic errors that, in James E. Lukaszewski's view, led to

\footnotetext{
${ }^{22}$ Moldovan, R., Tolnai, T., Naumescu, V., Crisis: ICDE voices during the pandemic, Timisoara: Western University Publishing House, 2020, pp. $17-24$.

${ }^{23}$ Bârgăoanu, A., The hierarchy of sources of misinformation and the values of distrust, in the Chronicles. Governance course. Corona - Zoom in on the EU lag. Nr. 93, March 2020, p. 7.

${ }^{24}$ Mihalache, A. S., Dulcan, D.C., Pan-demon 2020 and Covid-19. A book-document about Spring 2020, Iasi: Sedcom Libris Publishing House, 2020.
} 
excessive responses, which made secondary crises much more difficult to manage. These responses are: hesitation (which has led to a public perception of confusion, insensitivity, incompetence, or lack of preparation), confusion (which has led to the perception of dishonesty and insensitivity), distortion or misunderstanding big problem, because nothing can replace the truth), dogmatization (which induces vulnerability, by resorting to an autocratic approach without actually managing the current problem), confrontation (which supplements the degree of visibility by maintaining the problem).

\subsection{Case study - 2020 Parliamentary elections in Romania}

Romania in 2020 is the typical scenario of a state in which the pandemic democracy had a significant impact on the results of the general elections, when people chose their representatives in the Senate and the Chamber of Deputies.

The parliamentary elections for the appointment of 136 senators and 329 deputies took place on December 6, 2020, after the elections for the local public administration authorities took place in June of the same year, this being the fourth electoral competition organized during 18 months. The initial proposal was for the parliamentary elections to take place in March 2021, but it was rejected by the government, which announced the election date only 3 months before the election. It is important to understand that the election took place in the conditions of official reports indicating over 5200 infected people / day and over 130 deaths / day.

The COVID-19 pandemic exacerbated structural problems in Romania, from the collapse of the public health system to the closure of several economic sectors affected by the health crisis, so that opposition parties frequently fed the public space with attacks and criticism of power. As a result, the power (the National Liberal Party) did its best to remain in the lead throughout the election campaign, making excessive use of government powers. Thus, in September 2020, the Government imposed to the Parliament the adoption of a series of amendments that targeted several laws related to elections. The main measures were to extend by 30 days the period for submitting the application for voting by mail, to extend the vote abroad for two days, to halve the number of signatures required for the registration of a candidate and the possibility of submitting them electronically. With regard to these changes, OSCE SEAM, which was invited and accredited to oversee the elections, noted that there were adopted "in a hasty manner and without public debate, contrary to international commitments and good practice"25. Also, Expertforum, a local CSO coalition that acted as an election observer, expressed concern about the timeliness of the changes.

\footnotetext{
${ }^{25}$ Report on preliminary findings and conclusions, International Election Observation, ODIHR Special Mission for Election Assessment, Romania - Parliamentary Elections, 6 December 2020, Organisation for Security and Cooperation in Europe, https://www.osce.org/files/f/documents/c/d/472878_0.pdf, pp. 2-3.
} 
The measures adopted by the Government made it unlikely to carry out a classic election campaign, with the restriction of gathering in closed spaces of more than 20 people, using a protective mask. In this situation, the parties that competed in the elections deployed their forces in the online space, where the election messages flooded personal pages, pages of organizations, social groups and even groups of small advertisements. There were also propaganda and fakenews tools, respectively astroturfing and trolling. The campaign was more dynamic on social networks than in the traditional media and focused on issues related to economic recovery, maintaining social benefits or anti-corruption, and the worsening health situation gave rise to serious allegations of corruption. Opposition leaders have sanctioned the power for abuses in the exercise of legal prerogatives during the campaign, contrary to international standards.

The hierarchy of misinformation sources, according to a Reuters questionnaire applied in Romania in June 2020, regarding reliable sources during the pandemic and public perception of misinformation sources, is as follows: some politicians (59\%), ordinary people they do not know personally (51\%), news organizations $(49 \%)$, government $(46 \%)$, ordinary people they know personally $(41 \%)$, national health organizations $(37 \%)$, global health organizations $(36 \%)$, scientists, doctors, other health experts (32\%) - see Appendix Chart. What is certain is that, in Romania, "the battle in the communication space was not one between facts, but between interpretations and, especially, between previous beliefs and moods that marked those interpretations"26. Specifically, the online space was invaded by information about "the virus that does not exist", "the virus that exists only on TV", "the COVID masquerade" or the "planned pandemic", according to the report" COVID-19 infodemia in Romania. An analysis of misinformation in the digital space" (2020).

For the actual organization of the election, prevention and safety measures were adopted. Wearing a face mask was mandatory for all voters, except for the short period of time in which they had to be identified on the basis of the identity card, a social distance of at least 1 meter had to be observed and all polling stations were equipped with disinfectants. Upon arrival, the voter's temperature was measured at the entrance of the polling station, and the maximum number of people at the same time at a polling station was 15. At the entrance and exit, voters were forced to disinfect their hands. Voters mentioned in the electoral lists had the opportunity to vote in person during the elections day or were able to request the use of the mobile ballot box. Voters infected with Covid-19 or self-isolated voters voted either electronically or at home, after submitting a request to do so. These measures were generally followed, but OSCE noted that some polling stations were not spacious enough to respect social distancing.

26 The report COVID-19 infodemia in Romania. An analysis of misinformation in the digital space, Eurocomunicare, pg. 11, 2020, https://www.antifake.ro/infodemia-covid-19-in-romania/, accessed on 17.05.2021. 
According to the electoral register, a total of $18,970,649$ voters were registered in these elections. Turnout in the December 6 elections was lower than in the 2016 elections, from $39.49 \%$ to $34.81 \%$. The final results of the parliamentary elections placed the main opposition party in Romania on first place, with $28.9 \%$ of the votes. The ruling party, PNL, obtained $25 \%$ of the total number of votes. USR-PLUS ended the election race with $15 \%$, and AUR, an unknown party, non-existent in sociological research and visible only during the election campaign, with 9\%. PMP, ALDE and Pro Romania did not enter the Parliament, although they succeeded in obtaining good scores in the local elections.

\section{CONCLUSIONS}

As OSCE said, a genuine campaign and the real public debate are as important for democratic elections as the right to vote. The Coronavirus crisis has had a profound impact on the ability of states around the world to guarantee the provision of public services and electoral events that are an integral part of inclusive societies, while providing an ambiguous and opaque framework for democratic values and standards.

Faced with an extraordinary situation, such as responding promptly and effectively to an unknown pandemic, Governments have put pressure on democracy and the rule of law, and accentuated their authoritarian tendencies, by virtue of the desire of some leaders to strengthen control over power under the pretext of anti-pandemic restrictions. The Hungarian government, for example, has used anti-pandemic measures to disguise abuses and prevent access to verification of vaccine documentation by the medical staff. At the same time, Poland has restricted freedom of information and association in order to overturn protests against a controversial abortion law, according to the Civil Liberties Union for Europe, a human rights organization in the European Union.

On the other hand, the accelerated legislative procedures that have come as a result of anti-pandemic restrictions made it difficult for citizens to participate in the democratic public debate. The lack of transparency and the lack of consultation with the public and civil society on issues of national interest have also been visible in strongly strengthened democracies, such as Germany, Sweden and Ireland. All this, together with the disproportionate restrictions imposed on free movement and free expression, or those on the press and the judiciary system, have shown that a health crisis can jeopardize or even overthrow the efforts of decades of grind with democratic values and norms. Governments that systematically undermine justice and civil society (Hungary, Poland), as well as those that have persistent problems with the rule of law and the independence of justice (Bulgaria, Romania), also have the greatest vulnerabilities.

The different ways in which the Coronavirus pandemic has impacted democratic electoral systems around the world came as a result different meaning 
that states give to the importance of democracy existence. More than being applied, democracy must be defended, a minimum core of electoral principles must be preserved, and this reveals a reality that is undeniable: the weaker and vulnerable a system is, including an electoral one, the greater the risk that that system will fall due to external factors (for example, a pandemic). We all are guardians of democracy, each one of us, as citizens who respect democratic values, norms and principles.

\section{BIBLIOGRAPHY}

- Bârgăoanu, A., The hierarchy of sources of misinformation and the values of mistrust, in the Chronicles. Course of government. Corona-Zoom on the EU phase. No. 93, March 2020.

- Cismaru, D.M., Ciochina, R.S., Public relations in the online environment, Bucharest: comunicare.ro Publishing House, 2019.

- Dobrescu, P., Crisis after crisis. A world without compass and without hegemon. Bucharest: Litera Publishing House, Kronika Collection, 2016.

- Larkin, J, Regester, M., Crisis and Risk Management, Bucharest: Comunicare.ro Publishing House, 2003.

- Mihalache, A. S., Dulcan, D.C., Pan-demon 2020 and Covid-19. A bookdocument about Spring 2020, Iasi: Sedcom Libris Publishing House, 2020.

- Moldovan, R., Tolnai, T., Naumescu, V., Crisis: ICDE voices during the pandemic, Timisoara: Western University Publishing House, 2020.

- Patrick, S., Weak States and Global Threats: Fact or Fiction?, in The Washington Quarterly, No. 29: 2, 2006.

- Wiener, A. J., Kahn, On Escalation, New York, Praeger apud. Lagadec, P., Preventing Chaos during Crises - Strategies for Combating, Controlling and Limiting Damage, London: McGraw - Hill Book Company, 2003.

\section{WEB Resources}

- Global overview of the impact of COVID-19 on elections, Institute for Democracy and Electoral Assistance, IDEA, https://www.idea.int/newsmedia/multimedia-reports/global-overview-covid-19-impact-elections.

- How COVID-19 changed everything about the 2020 elections, Time, August 2020, available at: https://time.com/5876599/election-2020-coronavirus/.

- Zamfir, I., Fardel, T., The impact of the pandemic on world elections. From security issues to political crises, EPRS - European Parliament Research Service, July 2020, https://www.europarl.europa.eu/RegData/etudes/ BRIE/2020/652017/EPRS_BRI(2020)652017_EN.pdf. 
- How can independent institutions overcome COVID-19 threats to protect democracy during the crisis? https://www.ifes.org/publications/ifes-covid19-briefing-series-preserving-independent-and-accountable-institutions.

- Declaration of Principles on International Election Observation, National Democratic Institute, https://www.ndi.org/sites/default/files/1923_ declaration_102705_en.pdf.

- Report on Preliminary Findings and Conclusions, International Election Observation, ODIHR Special Election Evaluation Mission, Romania Parliamentary Elections, 6 December 2020, Organization for Security and Cooperation in Europe, https://www.osce.org/files/f/documents/c/d/ 472878_0.pdf.

- Elections and measures taken during COVID-19, International Foundation for Electoral Systems: IFES, October 2020, https://www.ifes.org/sites/ default/files/elections_held_and_mitigating_measures_taken_during_covid19.pdf.

- Noury, A., François, A., Gergaud, O., Garel, A., How COVID-19 affected turnout. Case study on French municipalities, https://journals.plos.org/ plosone/article?id=10.1371/journal.pone.0247026.

- COVID-19 short series: preservation of independent and responsible institutions, International Foundation for Electoral Systems (IFES), https://www.ifes.org/publications/ifes-covid-19-briefing-series-preservingindependent-and-accountable-institutions.

- Landman, T., Pandemic Democracy: Elections and COVID-19, May 2020, https://www.tandfonline.com/doi/full/10.1080/13669877.2020.1765003.

- Elections and Covid-19: international election observation in 2020, Institute for Democracy and Electoral Assistance, IDEA, https://www.idea.int/newsmedia/news/elections-and-covid-19-international-electoral-observation2020.

- Gherasim, C., Covid-19: Democracy and the rule of law under pressure in the EU, EUObserver, Bucharest, March 2021, https://euobserver.com/ coronavirus/151376.

- Principles for the protection of civil and political rights in the fight against Covid-19, March 2020, available at: https://freedomhouse.org/article/ principles-protecting-civil-and-political-rights-fight-against-covid-19.

- Coronavirus postpones elections around May 2020, https://foreignpolicy.com/2020/05/22/coronavirus-elections-postponedrescheduled-covid-vote/.

- Drăghici, M., Pandemic eroded democracy and the rule of law in many EU countries, including Romania, March 2021, https://www.mediafax.ro/ social/organizatie-pandemia-a-erodat-democratia-si-statul-de -right-in-manyeu-countries-including-romania-19950571. 
- Elections in the context of the COVID-19 pandemic, https://www.roaep.ro/ prezentare/stire/alegerile-in-contextul-pandemiei-de-covid-19/.

- Elections and COVID-19, https://www.electoralintegrityproject.com/ elections-and-covid19.

- Report "COVID-19 infodemia in Romania. An analysis of misinformation in the digital space", Eurocommunication, October 2020, https://www.antifake.ro/infodemia-covid-19-in-romania/.

\section{Appendix}

Charts - Turnout in regional and national elections in the COVID-19 pandemic

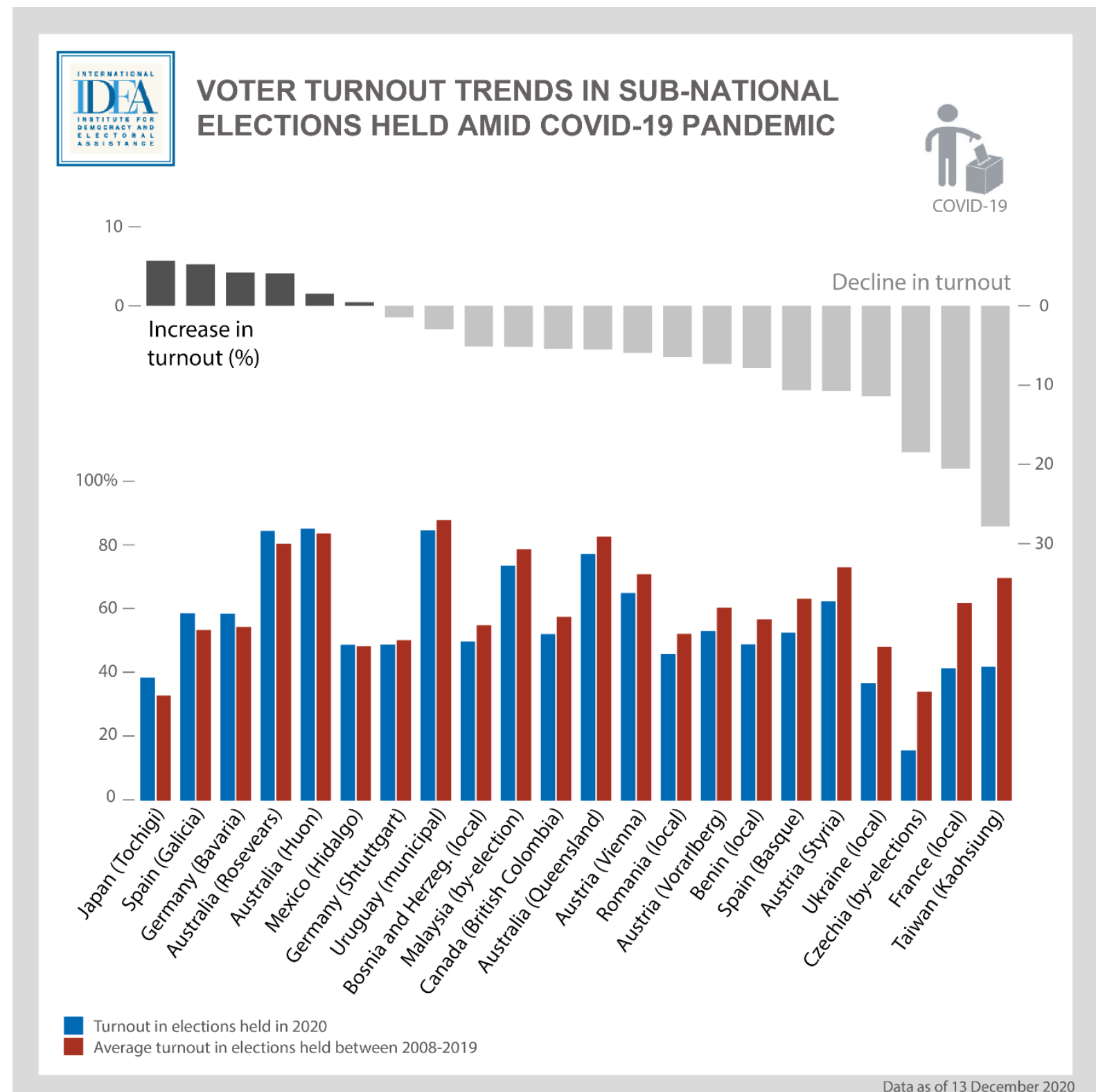


Strategies XXI - ACNDC

Bucharest, June 25, 2021

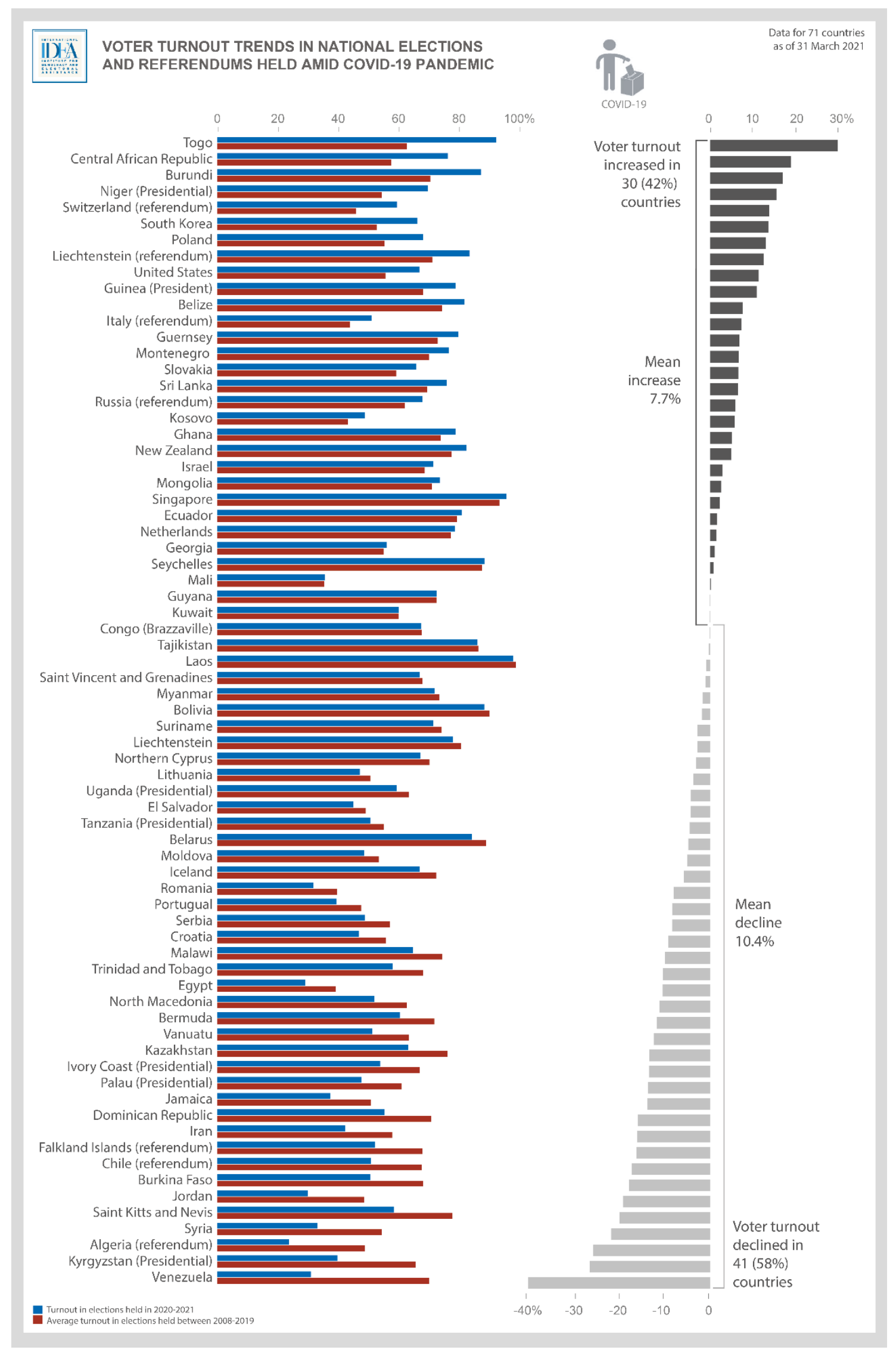


The hierarchy of disinformation sources in Romania and 6 other countries of the world

IERARHIA SURSELOR DE DEZINFORMARE ÎN ROMÂNIA ȘI ÎN ALTE 6 TĂRI DIN LUME

- REGATUL UNIT AL MARII BRITANII

Persoane obisnuite pe care nu le cunosc personal

Anumiti politicieni

Organizațile de stiri

Guvernul

Persoane obignuite pe care le cunosc personal

Organizatii internationale din domeniul sảnăt áții

Organizații naționale din domeniul sànat aţii

Oameni de știință, doctori, alți experți din domeniul sănát âtî

\section{GERMANIA}

Persoane obisnuite pe care nu le cunosc personal

Anumiti politicieni

Organizațiile de știri

Guvernul

Persoane obisnuite pe care le cunosc personal

Organizatiii internationale din domeniul sảnăta ătii

Organizații naționale din domeniul sànat áţii

Oameni de știinţă, doctori, alți experți din domeniul sănătáții

- COREEA DE SUD

Persoane obisnuite pe care nu le cunosc personal

Anumiți politicieni

Organizațile de știri

Guvernul

Persoane obisnuite pe care le cunosc personal

Organizații internaționale din domeniul sảnătătii

Organizatii nationale din domeniul sànátătii

Oameni de știinţă, doctori, alți experți din domeniul sănătății

- ROMÂNIA

Persoane obişnuite pe care nu le cunosc personal

Anumiţi politicieni

Organizatilie de stiri

Guvernul

Persoane obis nuite pe care le cunosc personal

Organizații internaționale din domeniul sảnătății

Organizații nationale din domeniul sănăt ătii

Oameni de știință, doctorí, alți experți din domeniul sảnătáții

- STATELE UNITE ALE AMERICII

Persoane obisnuite pe care nu le cunosc personal

Anumiți politicieni

Organizatilie de stiri

Guvernul

Persoane obisnuite pe care le cunosc personal

Organizații internaționale din domeniul sănătâții

Organizatii nationale din domeniul sànàtátiii

Oameni de sttinţă, doctori, alți experti din domeniul sănăt atsii

\section{- SPANIA}

Persoane obişnuite pe care nu le cunosc personal

Anumitị politicieni

Organizațile de știri

Guvernul

Persoane obisnuite pe care le cunosc personal

Organizații internationale din domeniul sănăta țtii

Organizatii naționale din domeniul sànătătii

Oameni de știinţă, doctori, alți experți din domeniul sànăt áţi

\section{ARGENTINA}

Persoane obisnuite pe care nu le cunosc personal

Anumiti politicieni

Organizațile de știri

Guvernul

Persoane obisnuite pe care le cunose personal

Organizatii internationale din domeniul sànăt ât

Organizații naționale din domeniul sảnătății

Oameni de știinţă, doctori, alți experți din domeniul sănătăți
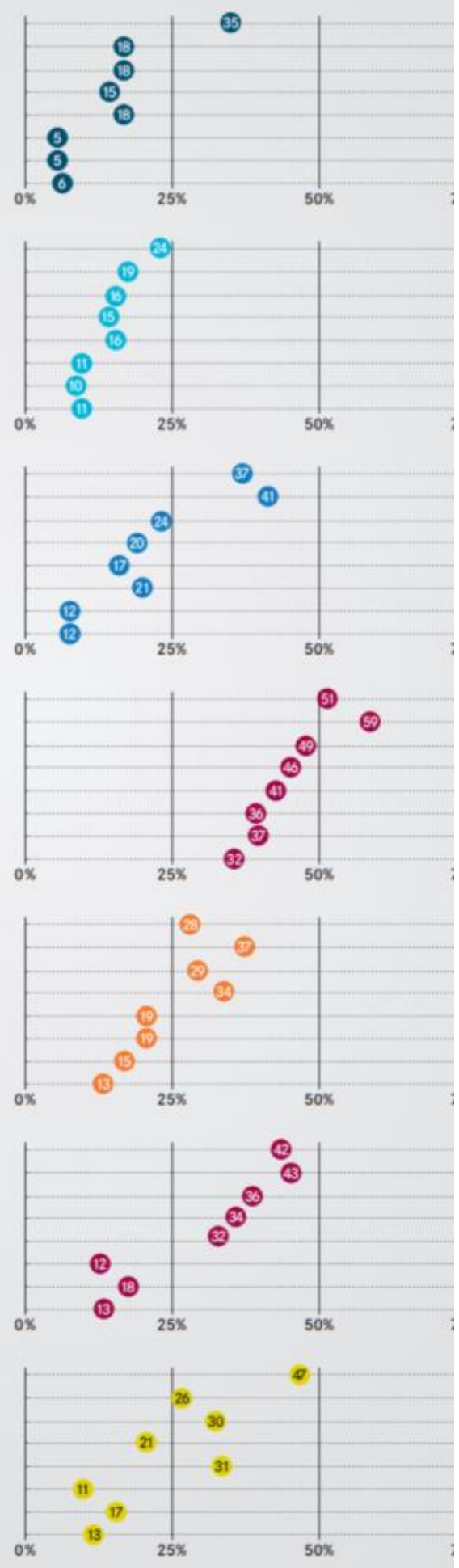